\title{
Effect of Wastewater from Hydroponics Culture on Lettuce Cultivation
}

\author{
Dr. Prathima Seechurn Poonpoon, and Dr. Bhanooduth Lalljee
}

\begin{abstract}
The use of wastewater generated from open hydroponic systems in Mauritius was identified as being an important issue for crop production. In the present study hydroponic effluents at different dilution factor combined with the recommended fertiliser rate was investigated. The yield and nutrient composition of lettuce was accordingly considered. The experimental design chosen was entirely randomised, with four replications. Data were statistically analysed using analysis of variance (ANOVA) according to the statistical package. The treatments were T1: Control (no fertiliser and no hydroponic effluents), T2: $100 \%$ hydroponic effluents as per initial EC value, T3: Diluted hydroponic effluents to $1 / 2$ the initial EC value, $\mathrm{T} 4: 75 \%$ recommended mineral fertiliser rate $+25 \%$ of the mineral fertiliser applied in form of hydroponic effluents, T5: $100 \%$ recommended mineral fertiliser rate $(70 \mathrm{~kg} \mathrm{~N} / \mathrm{ha}, 71 \mathrm{~kg} \mathrm{P} / \mathrm{ha}, 93 \mathrm{~kg}$ $\mathrm{K} / \mathrm{ha}$ ). The accumulation of biomass from the lettuce plant shoots subjected to the treatment with added hydroponic effluents showed the second best results $(13.14 \mathrm{t} / \mathrm{ha})$ for the mass production from the shoots as compared to the recommended mineral fertiliser rate which gave the highest yield of 14.68t/ha. As compared to the control plot (T1) where growth was not prominent treatment T2 $(100 \%$ hydroponic effluents) reached to 92,300 units/hectare and treatment T5 (100\% recommended mineral fertiliser) reached to 93,200 units/hectare. The treatment with $100 \%$ recommended mineral fertiliser rate showed significantly higher levels of N, P and $\mathrm{K}$ in the plants followed by $100 \%$ hydroponic effluents. The study revealed appreciable results thereby indicating that the hydroponic effluents are a good source of fertiliser.
\end{abstract}

Keywords: hydroponic effluents, yield, lettuce, environment, recommended mineral fertiliser rate.

\section{INTRODUCTION}

The use of waste products in agriculture provides an approach for recycling of nutrients. Hydroponic effluents the end waste from greenhouses can be reused for agricultural purposes. In view of protecting our natural environment hydroponic effluents have appeared as a supplementary substitute use of fertiliser, although the positive effects of hydroponic effluents in crop production is very limited in Mauritius. The plant selected was Lactuca sativa L. var. (lettuce) due to the fact that this crop is considered as one of the highest accumulators of nitrates in the leaves (Merino 2006). Lettuce is a short-cycle annual vegetable, with large leaves and rapid growth. It adapts best to lower temperatures, requiring wide temperature variations and high relative humidity (Cermeño, 1990). Faced with the lack of works to

Dr Prathima Seechurn Poonpoon, University of Mauritius, Mauritius Dr Bhanooduth Lalljee, University of Mauritius, Mauritius evaluate the effects of hydroponic effluents in agricultural crops, the objective of the present work was sought to quantify the shoot mass production of lettuce plants, as well as foliar nitrogen, phosphorus, potassium and other elements content following the application of hydroponic effluents.

\section{FIELD EXPERIMENT}

The treatments were as follows: T1: Control (no fertiliser and no hydroponic effluents), T2: 100\% hydroponic effluents as per initial EC value, T3: Diluted hydroponic effluents to $1 / 2$ the initial EC value, T4: $75 \%$ recommended mineral fertiliser rate $+25 \%$ of the mineral fertiliser applied in form of hydroponic effluents, T5: $100 \%$ recommended mineral fertiliser rate $(70 \mathrm{~kg} \mathrm{~N} / \mathrm{ha}, 71 \mathrm{~kg} \mathrm{P} / \mathrm{ha}, 93 \mathrm{~kg} \mathrm{~K} / \mathrm{ha})$. The rate of hydroponic effluents used under this experiment was 453 L/ha. The Electrical Conductivity (EC) of the hydroponic effluents was $1.4 \mathrm{mS} / \mathrm{cm}$ having a nitrate concentration of 240 $\mathrm{mg} / \mathrm{L}$. Uniform seedlings raised in seed trays were used as transplant. 45 days after plantation, the lettuce crop was harvested and the shoot dry mass was noted.

\section{DATA ANALYSIS}

The experimental design chosen was entirely randomised, with four replications. Data were statistically analysed using analysis of variance (ANOVA) according to the statistical package. Probabilities of significance among treatments and LSD $(\mathrm{P} \leq 0.05)$ were used to compare means between treatments. The hypothesis set for this experiment was as follows: $\mathrm{H}_{\mathrm{o}}$ : Hydroponic effluents will not increase the yield of lettuce and $\mathrm{H}_{1}$ : Hydroponic effluents will increase the yield of lettuce.

\section{Plant SAmpling And ANAlyseS}

Samples for the determination of mineral nutrients were prepared using dry ashing method. $2 \mathrm{~g}$ of oven dried sample was weighed each into a porcelain crucible, pre ashed, then ashed in a furnace at $450^{\circ} \mathrm{C}$ until a white ash remains. The ash was then dissolved into $20 \mathrm{~mL}$ of $1 \mathrm{M} \mathrm{HCl}$ and transferred into a $100 \mathrm{~mL}$ beaker which was placed in a boiling water bath for 30 minutes to complete digestion. The suspension was filtered on Whatman filter paper into a $100 \mathrm{~mL}$ volumetric flask. The filtrate was washed several times with distilled water and made up to $100 \mathrm{~mL}$. The total kjeldahl nitrogen content was determined using the macro-kjeldahl technique - Gerhardt Kjeldatherm, Germany (Rowell, 1994). Phosphorus content was also determined by the Rowell method. As regards to 
potassium, after dilution of the original ash solution to $1 / 5$, the emission was measured in an air-propane flame at wavelength $768 \mathrm{~nm}$. The other trace elements were then determined by atomic mass spectrophotometer.

\section{RESULTS}

Lettuce treated with the $100 \%$ recommended mineral fertiliser rate showed higher shoot dry mass production of $14.68 \mathrm{t} / \mathrm{ha}$ followed by $13.14 \mathrm{t} / \mathrm{ha}$ from treatment (T2) $100 \%$ hydroponic effluents (Figure 1.0). The yield obtained was directly related to the nutrients in the hydroponic effluents thus demonstrating that the concentration of the nutrients was necessary for the constructive and significant response. When comparing the treatments, significant differences were observed $(p<0.05)$ in the shoot biomass production. Plants cultivated with water only did not attain full development, possibly because of very low amount of nitrogen in the soil. As compared to the control plot (T1) where growth was not prominent treatment T2 (100\% hydroponic effluents) reached to 92,300 units/hectare and treatment T5 (100\% recommended mineral fertiliser) reached to 93,200 units/hectare.

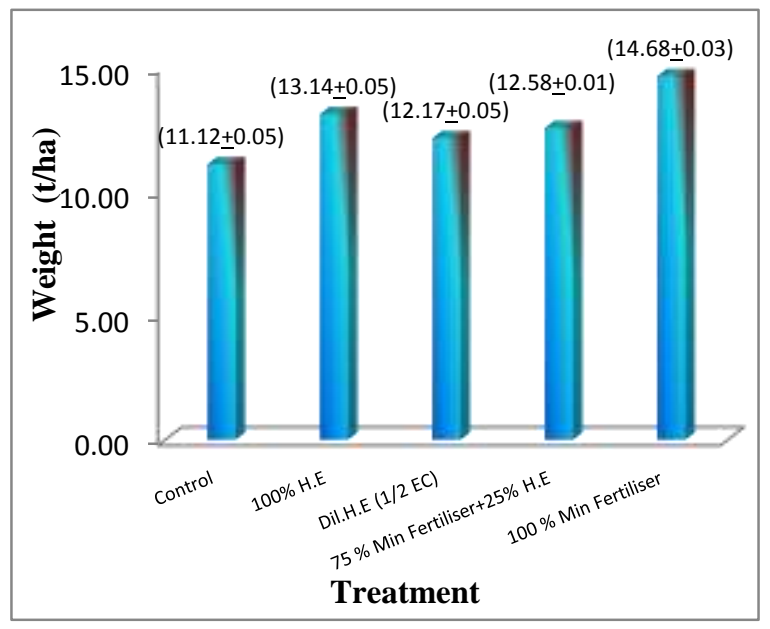

Fig. 1: Dry mass production (t/ha)

Morever, the diameter of lettuce plants differs by only $6 \%$ from the recommended mineral fertiliser rate $(\mathrm{T} 5-30.75 \mathrm{~cm})$ to that of the $100 \%$ hydroponic effluents only $(\mathrm{T} 2-28.56 \mathrm{~cm})$ as per Figure 2.0.

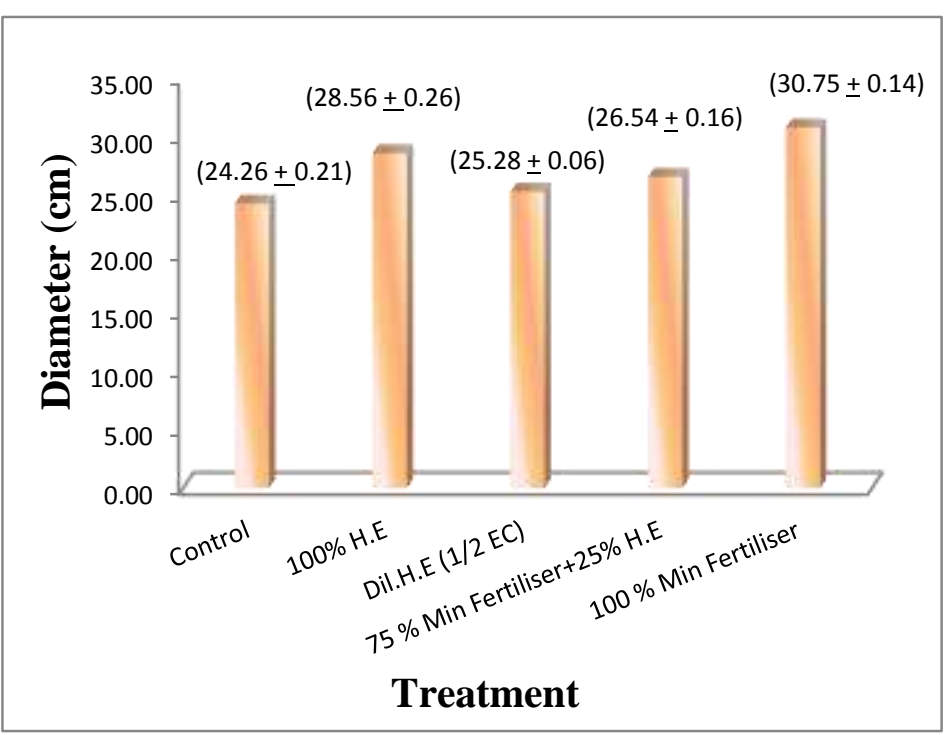

Fig. 2: Characterisation of lettuce

\section{Nutrient analysis of lettuce plants (N, P \& K)}

Table 1.0 below shows the accumulation of nitrogen, phosphorus and potassium from lettuce plants. The two highest values of $\mathrm{N}, \mathrm{P}$ and $\mathrm{K}$ were found in Treatment T5 and T2 respectively. This implies that the source of fertiliser applied plays a very important role thereby resulting in increased yield.

TABle I: Accumulation Of Nitrogen (N), Phosphorus (P) And Potassium (K) From LetTUCE Plant (\%)

\begin{tabular}{|l|c|c|c|}
\hline \multicolumn{1}{|c|}{ Treatment } & Nitrogen & Phosphorus & Potassium \\
\hline T1: Control & 0.001 & 0.190 & 0.078 \\
\hline $\begin{array}{l}\text { T2: } 100 \% \text { Hydroponic } \\
\text { Effluents }\end{array}$ & 0.005 & 0.208 & 0.104 \\
\hline $\begin{array}{l}\text { T3: Diluted Hydroponic } \\
\text { Effluents (1/2 EC) }\end{array}$ & 0.003 & 0.197 & 0.089 \\
\hline $\begin{array}{l}\text { T4: 75\% Recommended } \\
\text { Mineral Fertiliser + 25\% } \\
\text { Hydroponic Effluents }\end{array}$ & 0.004 & & \\
\hline $\begin{array}{l}\text { T5: } 100 \% \text { Recommended } \\
\text { Mineral Fertiliser }\end{array}$ & 0.007 & 0.205 & 0.092 \\
\hline
\end{tabular}

Figure 3.0 depicts the calcium and magnesium accumulation in lettuce plants per treatment. Treatment T2 (100\% hydroponic effluents) showed more or less same amount of $\mathrm{Ca}$ and $\mathrm{Mg}$ accumulation in the lettuce plants. This source of nutrients is mainly derived from the hydroponic effluents used to irrigate the plants. However, treatment T5 (100\% recommended mineral fertiliser rate) showed the highest value of magnesium accumulation which again was mainly derived from the source of fertiliser used. The lesser the amount of fertiliser used the lesser the calcium and magnesium accumulation in plants. 


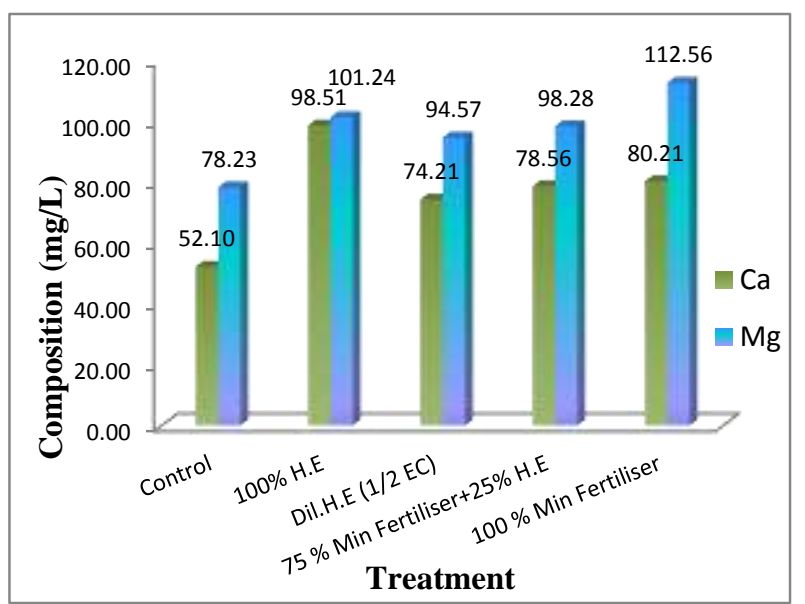

Fig. 3: Calcium and magnesium content in lettuce plants

Table 2.0 illustrates the other nutrient composition of lettuce plants. The sodium, sulphur and manganese content were high as compared to zinc, iron, copper and chromium content. Significant differences $(p<0.05)$ were observed with regard to the accumulation of nutrients in lettuce leaves. This could be highly due to the application of wastewater (T2) and $100 \%$ recommended mineral fertiliser (T5).

\begin{tabular}{|l|c|c|c|c|c|}
\multicolumn{4}{c|}{ TABLe II: Composition Of Lettuce PlanTs } \\
\cline { 2 - 6 } Nutrient & \multicolumn{5}{c|}{ Composition (mg/L) } \\
\cline { 2 - 6 } & T1 & T2 & T3 & T4 & T5 \\
\hline Sulphur & 9.28 & 9.62 & 10.11 & 10.21 & 10.63 \\
\hline Sodium & 6.24 & 9.54 & 8.01 & 8.25 & 10.26 \\
\hline Manganese & 8.54 & 11.64 & 8.86 & 8.88 & 11.95 \\
\hline Zinc & 0.62 & 0.94 & 0.74 & 0.89 & 1.21 \\
\hline Iron & 2.20 & 3.05 & 2.32 & 2.61 & 3.44 \\
\hline Copper & 0.72 & 1.08 & 0.88 & 0.96 & 1.24 \\
\hline Chromium & 2.33 & 2.57 & 2.36 & 2.50 & 2.59 \\
\hline
\end{tabular}

\section{Contribution of $\mathbf{N}$ from hydroponic effluents}

Table 3.0 shows the contribution of $\mathrm{N}$ per hectare of land. The highest $\mathrm{N}$ content was $432 \mathrm{~kg} \mathrm{~N} /$ ha from treatment $\mathrm{T} 2$ (100\% hydroponic effluents) followed by $360 \mathrm{~kg} \mathrm{~N} / \mathrm{ha}$ from treatment T5 (100\% recommended mineral fertiliser). This implies that the hydroponic effluents are very effective as it enriches the soil quality for the next crop to be cultivated. However treatment T3 and T4 showed a lower N content per hectare as compared to the initial soil content which was 288 $\mathrm{kg} \mathrm{N} / \mathrm{ha}$. It might be that the plants have used the $\mathrm{N}$ present in the soil as the $\mathrm{N}$ supplied from the fertiliser was not enough to sustain growth.
TABLE III: CONTRIBUTION OF N PER HECTARE OF LAND

\begin{tabular}{|l|c|}
\hline Treatment & $\begin{array}{c}\text { Amount of N } \\
\text { (kg N/ha) }\end{array}$ \\
\hline $\mathrm{T}_{0}$ : (Soil before transplantation) & 288 \\
\hline T1: Control & 144 \\
\hline T2: $100 \%$ Hydroponic Effluents & 432 \\
\hline $\begin{array}{l}\text { T3: Diluted Hydroponic effluents }\left({ }^{1} / 2\right) \\
\text { EC }\end{array}$ & 216 \\
\hline $\begin{array}{l}\text { T4: 75\% Recommended Mineral } \\
\text { Fertiliser + 25\% Hydroponic effluents }\end{array}$ & 216 \\
\hline $\begin{array}{l}\text { T5: 100\% recommended Mineral } \\
\text { Fertiliser }\end{array}$ & 360 \\
\hline
\end{tabular}

\section{DISCUSSION}

An increase in fresh weight in the lettuce was due to the high concentration of the hydroponic effluents. The nutrients present in the hydroponic effluents correspond to the high yield thus demonstrating that the presence of NPK in the mixture was vital for the constructive and positive response. When comparing the treatments, it was observed that there were statistically significant differences $(p<0.05)$ in the shoot biomass production (Figure 1.0). The accumulation of biomass from the lettuce plant shoots subjected to the treatment with added hydroponic effluents showed the second best results $(13.14 \mathrm{t} / \mathrm{ha}$ ) for the mass production from the shoots as compared to the recommended mineral fertiliser rate which gave the highest yield of 14.68t/ha. The high shoot yield in the $100 \%$ hydroponic effluents treatment was due to the superior balance in the chemical attributes of that waste compared to the others. The control treatment (T1) plot was very low in yield thereby indicating that growth was stunted due to the lack of important nutritional elements (Maynard and Hochmuth 1997). Moreover, differences in yield was not only associated with the amount of nitrogen added to the soil via the hydroponic effluents, but rather the amounts of the other nutrients (phosphorus, potassium, calcium and magnesium), biological activity and various forms of $\mathrm{N}$ when compared to the control treatment. The other elements found in the hydroponic effluents also help in promoting growth of the lettuce plants. Hydroponic effluents application on the soil resulted to an accumulation of nitrogen, phosphorus and potassium in lettuce leaves $(p<0.05)$, Table 1.0. The treatment with $100 \%$ recommended mineral fertiliser rate showed significantly higher levels of $\mathrm{N}, \mathrm{P}$ and $\mathrm{K}$ in the plants followed by $100 \%$ hydroponic effluents. It should also be noted that the $100 \%$ hydroponic effluents treatment allowed higher rate of accumulation as compared to the control treatment. Moreover, the $\mathrm{N}$ content in lettuce leaves was below the maximum limit for nitrate in lettuce established by the European Commission (2005). In fact, the nitrate concentration of lettuces leaves depends more on fertiliser type, dose or repeated applications (accumulative effect) than on the time of the year in which the crop is grown and these results confirmed that the fertiliser type plays a very crucial role (Pavlou et al. 2007). The accumulation of calcium content in lettuce plants was $98.51 \mathrm{mg} / \mathrm{L}$ for treatment $\mathrm{T} 2$ (100\% hydroponic effluents) and that of Treatment T5 (100\% 
recommended fertiliser rate) was $80.21 \mathrm{mg} / \mathrm{L}$ (Figure 2.0). Treatment 2 had the highest $\mathrm{Ca}$ accumulation. In fact, calcium plays an essential role in plant development and overall plant health because it is a structural component of cell walls and it is necessary for cell growth and division. In lettuce an increase of calcium in the leaf tissues can increase photosynthetic capacity and also chlorophyll synthesis (Reiss and Beale, 1996; Fallovo et al. 2009). In addition, increasing the calcium content in the leafy vegetables could further improve their nutritional benefits to the consumers considering that calcium is the mineral nutrient most commonly deficient in modern diets (Grusak, 2002). Hence the calcium derived from the hydroponic effluents plays a positive role in the lettuce production. Magnesium also is important for the metabolic activity because it is related to many enzymes controlling the metabolism of carbohydrates, fats, proteins and electrolytes (Chakraborti et al. 2002). Therefore, the high magnesium content in the lettuce leaves would not have any side effect on health. Copper is an essential micronutrient for plant growth, but is required only in small amount and at a higher concentration it is toxic (Mahmood, 2006). The zinc and copper levels were well below the maximum permissible value $(60 \mathrm{mg} / \mathrm{kg}$ and $40 \mathrm{mg} / \mathrm{kg}$ ) in food proposed by WHO/FAO (Codex Alimentarius Commission, 2007) (Arora, 2008). As regards to the other elements in the lettuce plants the sulphur, sodium and manganese were higher as compared to zinc, iron, copper and chromium. Yet from the research conducted it can be deduced that the lettuce produced under hydroponic effluents treatments were safe for consumption.

\section{CONCLUSION}

People's concern about their health and well-being is increasing. As a result, the greenery appears as an important food. The results obtained in this study showed that it is possible to irrigate leafy vegetables with hydroponic effluents as the wastewater provided the necessary elements for growth and normal physiological activity of plants. The hydroponic effluents consist of the macronutrients which are of key importance, as they determine crop yield and the quality of crops. Plants cultivated with $100 \%$ hydroponic effluents appeared healthy when compared to the $100 \%$ recommended mineral fertiliser rate. Overall, the use of hydroponic effluents in crop production would definitely help in protecting the environment by decreasing the load of pollution.

\section{ACKNOWLEDGMENT}

The present work was partially supported by the Food and Agricultural Research and Extension Institute, Mauritius. The project was also sponsored by the Mauritius Research Council.

\section{REFERENCES}

[1] Cermeno, Z. S (1990). Estufas: instalações e manejo. Lisboa: Litexa.

[2] Merino L, Darnerud PO, Edberg U, Aman P, Castillo MDP. (2006). Levels of nitrate in Swedish lettuce and spinach over the past 10 years. Food Addit Contam. 23:1283-1289. https://doi.org/10.1080/02652030600930543

[3] Rowell, D. L. 1994 Soil Science: Methods and Applications Prentice Hall, UK.
[4] Maynard DN, Hochmuth GJ. (1997). Knott's Handbook for vegetables growers. 4th ed. New York: Wiley.

[5] Pavlou GC, Ehaliotis CD, Kavvadias AV. (2007). Effect of organic and inorganic fertilizers applied during successive crop seasons on growth and nitrate accumulation in lettuce. Sci Hortic. 111:319-325. https://doi.org/10.1016/j.scienta.2006.11.003

[6] Fallovo, C., Y. Rouphael, M. Cardarelli, E. Rea, A. Battistelli, and G. Colla. (2009). Yield and quality of leafy lettuce in response to nutrient solution composition and growing season. Journal of Food Agriculture and Environment 7: 456-462.

[7] Grusak, M. A. (2002). Enhancing mineral content in plant food products. Journal of the American College of Nutrition 21: 178-183. https://doi.org/10.1080/07315724.2002.10719263

[8] Chakraborti.S, Chakraborti T. Mandal.M, Mandal A, Das S, Ghosh S (2002) Protective role of magnesium in cardiovascular diseases: A review. Mol. Cell. Bioch., 238: 163-179. https://doi.org/10.1023/A:1019998702946

[9] Mahmood.T (2006). Response of Rice Seedlings to Copper Toxicity and Acidity", Journal of Plant Nutrition. https://doi.org/10.1080/01904160600651704

[10] Arora, M., Kiran, B., Rani, A., Rani, S., Kaur, B., \& Mittal, M. (2008). Heavy metal accumulation in vegetables irrigated with water from different sources. Food Chemistry, 111, 811-815. https://doi.org/10.1016/j.foodchem.2008.04.049

[11] WHO/FAO. (2007). Joint FAO/WHO Food Standard Programme Codex Alimentarius Commission 13th Session. Report of the Thirty Eight Session of the Codex Committee on Food Hygiene. Houston,United States of America.

About Author (s):

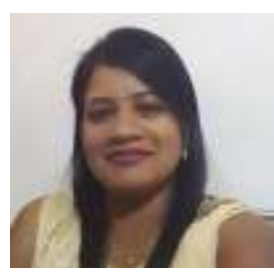

Hydroponic effluents: a good source of fertiliser 